\title{
The Phenomenology of Ritual Resistance: Colin Kaepernick as Confucian Sage
}

\author{
Philip J. Walsh
}

\begin{abstract}
:
In 2016, Colin Kaepernick, a quarterback for the San Francisco 49ers, remained seated during the national anthem in order to protest racial injustice and police brutality against African-Americans. After consulting with National Football League (NFL) and military veteran Nate Boyer, Kaepernick switched to taking a knee during the anthem for the remainder of the season. Several NFL players and other professional athletes subsequently adopted this gesture. This paper brings together complementary Confucian and phenomenological analyses to elucidate the significance of Kaepernick's gesture, and in the process provide a phenomenological characterization of the connection between the Confucian notions of sagehood and ritual. Kaepernick's gesture subverts the anthem ritual from within while simultaneously remaining faithful to the ideals it is meant to express. Furthermore, it institutes a new bodily form of patriotic self-expression compatible with both American and Confucian ideals.
\end{abstract}

\section{Keywords:}

Confucianism; Kaepernick; phenomenology; ritual; sagehood; patriotism

\section{Introduction}

In 2016, Colin Kaepernick, a quarterback for the San Francisco 49ers, remained seated during the national anthem in order to protest racial injustice and police brutality against AfricanAmericans. After consulting with National Football League (NFL) and military veteran Nate Boyer, Kaepernick switched to taking a knee during the anthem for the remainder of the season. Several NFL players and other professional athletes subsequently adopted this gesture. ${ }^{1}$ In this paper I argue that Kaepernick's gesture is a powerful exemplar of ritually expressed patriotism. My route to this conclusion, however, is unconventional. Much of the contemporary discourse on patriotism is illequipped to capture the significance of Kaepernick's gesture. Political liberalism tends to be generally uncomfortable with patriotism and the rituals that cultivate it - regarding it, at worst, as an irrational attitude akin to racism, or, at best, as something to be tolerated in an "attenuated" form (Keller 2005: 565). ${ }^{2}$ Patriotism is a virtue for the communitarian, but specific discussion of the rituals

\footnotetext{
1 The gesture has spread beyond professional sports to include an entire high school football team who has chosen to kneel for an entire season, as well as several non-athletic examples from around the world (see, e.g., Ortiz 2018; Diaz 2018; Sharon 2018; Bauer-Wolf 2019).

2 A full explication and defense of this characterization of liberalism and patriotism would take me far beyond the scope of this paper. For the dialectical purposes of this paper, I here follow Keller's (2005) rough characterization of the relationship between patriotism, liberalism (which he discusses as "universalism"), and communitarianism. For a more comprehensive overview see Primoratz (2008). At the strongest end of the spectrum, philosophers like Gomberg (1990)
} 
that cultivate it - let alone how political protest can find a home within those rituals - is lacking. The classic communitarian defense of patriotism as a virtue comes from MacIntyre, who argues that patriotism is a form of loyalty that recognizes one's home community, just as one recognizes one's parents, as the source — as the condition for the possibility of - their moral development. In other words, loyalty to one's community is a "prerequisite" for apprehending moral rules and the moral goods that justify them at all (MacIntyre 2003: 293). In this paper I do not take a position on whether patriotism is in fact valuable. My point is rather that Confucian social and political philosophy, understood as a form of communitarianism, and especially with regard to its explicit emphasis on the importance of ritual for cultivating communal loyalty, offers a superior set of resources for analyzing Kaepernick's gesture. Furthermore, while Confucian philosophy can help us gain a fruitful "macro" perspective on the significance of ritual in contemporary American life, a complementary phenomenological analysis of ritual goes beyond the resources of Confucianism and provides the necessary "micro" perspective on the concrete details of how political power functions at the affective-bodily level. In short, through mutually enriching Confucian and phenomenological analyses, this paper argues that Kaepernick's gesture teaches us something important about the enduring power of ritual and its role in the expression of patriotism in contemporary American society.

This is an exercise in comparative philosophy, but not in the sense of directly comparing Confucianism and phenomenology and highlighting points of overlap or disagreement. Rather, I seek to bring these traditions together by orienting them toward an object of joint attention. In doing so, we can understand something about the meaning of contemporary patriotism (in America, but perhaps more generally as well) and the nature of ritual, and in the process see how these two traditions stand to benefit from engagement with one another. Specifically, I focus on the connection between sagehood and ritual in classical Confucianism, particularly as discussed by Xunzi. In the Analects and the Mengzi sagehood is strongly connected not only to moral selfcultivation, but to the ability to cultivate morality in others and thereby have a socially transformative effect. The Xunzi $i$ offers a plausible explanation of this social force: the sage has a kind of insight into the nature and purpose of ritual and institutes proper forms of self-expression. Of course, sagehood is a rich concept with a complex history throughout classical and neo-

and Keller (2005) argue that patriotism is akin to racism or bad faith, respectively. Notable accounts of forms of patriotism that are compatible with liberalism include Appiah (1997) and Baron (2008). The classic statement of the value of patriotism for the communitarian comes from MacIntyre (2003), which I discuss below. 
Confucianism. ${ }^{3}$ I do not aim here to enumerate an exhaustive set of necessary and sufficient conditions for sagehood and then argue that a particular person meets these criteria. In calling Kaepernick a contemporary sage, I am certainly not arguing that he is the "embodiment of perfect, transformed human relationships and morality" (Wang 1999: 29, as cited by Angle 2009: 15), nor that he is the "culmination" of virtue (Angle 2009: 15). Rather, I am arguing that Kaepernick's gesture is a sagely one because it goes beyond adherence to and mastery of existing ritual propriety by instituting a new ritualized form of patriotic self-expression, and relating one's self to the state in a bodily mode. I choose the term “sage [sheng/聖]” rather than “gentleman [junzi/君子]” because Kaepernick's gesture goes beyond the kind of moral exemplarity ascribed to the junzi $i$ in early Confucian texts. The junzi $i$ is often described as perfectly harmonizing with existing institutions, mastering the prescribed ways of relating to others. The junzi does not institute new ways of relating. Sagely action, in contrast, is still guided by the ideal of harmonization, but transcends the mastery of the jun₹i in that it is capable of instituting new ways of relating, new forms of understanding one's role. Kaepernick's gesture disrupts existing ways of understanding one's connection to a political community while simultaneously seeking continuity and harmonization. This ability to innovate while maintaining reverence for certain ideals is, I argue, an important mark of sageliness. ${ }^{4}$

I proceed by situating the case of Kaepernick within different moral frameworks and argue that Confucianism offers a productive lens for understanding its significance ( $(2)$. I then draw on Sungmoon Kim's (2011) discussion of "Confucian incivility" to show not only that political protest has a home in Confucianism, but that the bodily format of ritual can itself be the modality of Confucian incivility (\$3). I further characterize the connection between sagehood and ritual, with emphasis on the nature of ritual as an extended historical project situated in a particular heritage (\$4). This sets the stage for a multi-faceted phenomenological analysis of how intersubjectivity, historicity, and the affective body intersect in ritual ( $(5)$. The phenomenological notions of incorporation, excorporation, and citational force further elucidate the ways in which ritual shapes us but can also be subverted from within (\$6). I conclude by considering how Kaepernick’s gesture offers an authentic expression of patriotism compatible with both Confucian and American ideals.

\footnotetext{
${ }^{3}$ See Angle (2009) for a comprehensive account of sagehood in the Confucian tradition, with particular focus on NeoConfucianism.

${ }^{4}$ See Angle (2009: 200-204) for the significance of the concept of reverence for understanding sagehood.
} 


\section{Show some respect}

To say that Kaepernick's gesture sparked a "national conversation" would be an understatement. Since the story broke in August 2016, the number of opinion pieces, television and radio hours, and social media posts devoted to fiery condemnations and passionate defenses of Kaepernick are beyond counting. ${ }^{5}$ The issue has even taken center stage in presidential politics. ${ }^{6}$ Critics and supporters alike tended to debate the issue in the vocabulary of rights and liberties characteristic of the political liberalism upon which America was founded. But this is not the appropriate register of normative discourse since Kaepernick clearly has the right to do what he did.

Critics tend to recognize this and yet still feel as though they have some standing to rebuke. Sure, he has the right, they think, but what he is doing is still wrong somehow. It is inappropriate or disrespectful. This is part of the reason why Confucianism can help us clearly articulate what is at stake in the disagreement. The Confucian grants the system of $l i$ (禮)—practices ranging from interpersonal etiquette to elaborate formal ritual—an explicitly political role. Confucius recommends that the populace be kept "in line by means of ritual," which is more effective than "coercive regulations" and "punishments" as means of maintaining order (Analects 2.3). Xunzi claims that "The fate of the state rests with ritual," and explains that the former kings established rituals "in order to divide things among people, to nurture their desires, and to satisfy their seeking" (Xunzi 17.198-199; 19.79). Rituals cultivate the emotions and attitudes that foster civility and collective identity. Thus, while American critics of Kaepernick are likely to concede that state power is not and should not be in the business of enforcing civic rituals in the interest of social harmony, the backlash against Kaepernick shows widespread implicit approval of a basic principle of Confucian statecraft—viz., the use of ritual to inscribe values upon the body politic.

This Confucian attitude toward ritual in America became especially pronounced in the realm of professional sport in the wake of the September 11, 2001 terrorist attacks. As sports writer Howard Bryant details, sports became an important cultural venue for crafting a narrative of strength, unity, and defiant resilience in the aftermath of the attacks:

\footnotetext{
${ }^{5}$ In one media analysis, a team of researchers drew a sample from a collection of the most trafficked sports news websites, local news websites, and national news websites from just one month in 2016, after the story broke, and ended up with a sample of 390 articles (Coombs et al. 2017: 52).

${ }^{6}$ In 2016 Barack Obama offered a characteristically nuanced defense of Kaepernick at a CNN presidential town hall (Diaz 2016). Kaepernick and the general issue of players kneeling was a frequent focus of Donald Trump's Twitter activity throughout 2016-2018, culminating in his call to "Get that son of a bitch off the field" at a campaign rally (Fritze 2018; Graham 2017). More recently, Texas senatorial candidate and later Democratic presidential candidate Beto O’Rourke gave a passionate defense of Kaepernick's actions that went viral on social media (Clark 2018).
} 
The ballpark was the place of defiance and the introduction of a new, post-9/11 character: heroes. On the field, the players had always been the ones celebrated as heroes. Now sports would recognize the off-field citizen in uniform as heroes too: police, fire, military, sometimes emergency services. The ballpark atmosphere made sports the perfect venue for that form of tribute...Fans expected every other fan in the ballpark to go along with the spectacle, to act right. Hand on heart. Sing along, or you were the problem. (Bryant 2018: 111) Patriotic displays at sporting events became occasions in which expressing the appropriate attitudes superseded concern for rights and liberties. For example, in August 2008 New York Yankee fan Bradford Campeau-Laurion was forcibly restrained and ejected from the stadium by uniformed police officers for trying to go to the bathroom while "God Bless America" was being played. "“God Bless America' was being played. It wouldn't kill him to wait a minute, would it?” remarked Sue Coster of Waterbury, Connecticut to the New York Times, "If they tried to do that in my aisle, I would have stuck out my leg” (as quoted by Bryant 2018: 154). This remark is illustrative of the general backlash against Kaepernick and the inadequacy of the language of rights and liberties. For many, Kaepernick's gesture is deeply offensive to their sense of what is appropriate. And regardless of their understanding of basic American legal principles, they do not hesitate to marry this sense of appropriateness with their sense of political obligation.

While the Kaepernick supporter may be rightfully exasperated by such attitudes, she should not find them very surprising. For it turned out that the post-9/11 Pentagon embraced some basic principles of Confucian statecraft. The frequency and intensity of patriotic rituals at sporting events was not an organic and spontaneous expression of an invigorated populace. They were actually the result of a systematic Department of Defense spending program, which devoted upwards of $\$ 6.8$ million to the effort (McCain and Flake 2017). ${ }^{7}$ In the wake of the Kaepernick controversy, the NFL instituted a policy requiring players to stand for the anthem or be fined, a move publicly urged and by the US President (who went on to criticize the policy for not being severe enough) (Brinson 2018).

\section{Democracy and Confucian Incivility}

If Kaepernick's critics seem more comfortably aligned with the conservatism of a Confucian communitarianism, with its attendant emphasis on fostering a harmonious body politic through

\footnotetext{
7 See also Davis (2018) for a more detailed history of how the NFL has proactively integrated patriotic ritual into its events in order to align itself with the conservative values of its fan base.
} 
state-sanctioned rituals, then one may be tempted to see Kaepernick's gesture as a characteristically American rebuke of that way of thinking: a bold expression of the individualism enshrined in America's liberty-protecting rights, namely the right to free speech. Seeing Kaepernick this way is natural given that, in many ways, Confucianism does not seem compatible with American democracy (or, at least, its purported ideals). The centrality of ritual to Confucian moral and political life is perhaps the most obvious point of difference. As Curzer notes:

Rituals inculcate values through repetition and passion rather than reason. They do not use explanation and persuasion to transmit values, but rather they slip values into people under reason's radar. Moreover, many rituals condition people from childhood when they are unable to think critically about values. Overall, rituals indoctrinate. (Curzer 2012: 299)

Whereas liberalism sees open and robust public discourse as the means to achieving consensus, the Confucian sees ritual as the principle mechanism of fostering civility and thereby achieving transgenerational social stability. In this way Confucianism is essentially conservative, and helps us properly understand what Kaepernick's critics are mad about. They may not have any standing to rebuke him from the position of liberalism, but insofar as they are implicitly committed to certain Confucian ideas about appropriateness, civility, and public rituals, we can better see where they are coming from. But what does Confucianism have to offer defenders of Kaepernick? It seems as though liberalism gives the Kaepernick enthusiast everything she needs: rituals are a pernicious nondemocratic form of achieving consensus, and in exercising his right to free speech by engaging in political protest during our most powerful patriotic ritual, Kaepernick's gesture embodies what America is really all about.

I do not think that this liberal rejoinder fully captures the significance of Kaepernick's gesture. In fact, I argue that Confucianism is relevant not only to understanding the rebuke of Kaepernick, but also in voicing a full-fledged defense and appreciation of him. First of all, Confucius never advocated a blind obedience to ritual. He is open to changes of ritual that modify the letter while preserving the spirit:

The Master said, "A ceremonial cap made of linen is prescribed by the rites, but these days people use silk. This is frugal, and I follow the majority. To bow before ascending the stairs is what is prescribed by the rites, but these days people bow after ascending. This is arrogant, and — though it goes against the majority-I continue to bow before ascending." (Analects 9.3) 
A certain degree of flexibility thus seems permissible when it comes to Confucian li. Confucius is fine with the simpler, more frugal ceremonial caps because they do not interfere with the meaning of the ritual. He disapproves, however, when it comes to bowing after one has already ascended the steps of a ruler's dais, as this alters the meaning of the ritual. In order for the ritual to express the proper attitude toward one's ruler - humility, deference, reverence - one must not presume permission to ascend.

This point, however, does not go very far in the way of arguing for a less conservative form of Confucianism compatible with contemporary American democracy. It is difficult to imagine, on the basis of this passage about ceremonial caps, a Confucian approving something as disruptive as Kaepernick's gesture, which is done as an explicit protest. There are additional Confucian resources, however, that allow for a Confucian appreciation of Kaepernick. Chaibong, drawing on Foucault, argues that Confucian rituals actually fill an important lacuna in democratic theory, offering “concrete ways in which freedom can be exercised" (Chaibong 2001: 315-316). This point becomes apparent with closer attention to certain discussions of $l i$ in different classical Confucian texts. The fullest expression of $l i$ by the morally exemplary demands active engagement and reflection, as opposed to the "petty man" who merely goes through the motions or is overly conspicuous.

In a famous passage from the Analects, for example, Confucius makes it clear that ritual propriety involves a certain attitude of being “fully present." When performing ritual sacrifice, "you should comport yourself as if the spirits were present," for, Confucius declares, "If I am not fully present at the sacrifice, it is as if I did not sacrifice at all” (Analects 3.12). Rituals become ossified and meaningless when everyone simply goes through the motions. It can be challenging to engage with ritual in a thoughtful, intentional way over and over again. The contemporary American anthem ritual, especially as it is practiced at massive professional sporting events, is especially susceptible to this threat because of its scale. It is easy to simply blend in with the throngs of people standing erect, hats removed, hands over hearts. While the critic might still disapprove of Kaepernick's gesture for being a disrespectful, they should nevertheless grant that he is engaging the ritual in a deliberate and "fully present" manner. If nothing else, Kaepernick is clearly taking the ritual seriously. His engagement with the ritual aligns with Chaibong's characterization of the potential of ritual in a modern democracy; rituals can provide "the basis for the active, participatory practices of the citizen of a modern democracy" (Chaibong 2001: 322).

But what about intentional, outright violations of ritual as a form of political protest or civil disobedience? First of all, as has been noted in the literature, Confucianism can and does endorse 
civil disobedience in certain circumstances, particularly in the form of ministers remonstrating rulers who have gone astray. ${ }^{8}$ Obsequious ministers who do not oppose their rulers can be the downfall of the state:

Duke Ding asked, "A single saying that can cause a state to perish-is there such a thing as this?" Confucius replied, "There is no saying that can have that sort of effect. There is, however, something close. People have a saying, 'I take no joy in being a ruler, except that no one dares to oppose what I say.' If what the ruler says is good, and no one opposes him, is this not good? On the other hand, if what he says is not good, and no one opposes him, does this not come close to being a single saying that can cause a state to perish?” (Analects 13.15)

Furthermore, when Zilu asks Confucius about serving his lord, Confucius straightforwardly replies, "Do not deceive him. Oppose him openly" (Analects 14.22).

The Mengzi repeatedly makes claims about when and how to properly restrain political power. The job of the minister is to "curb" or "shepherd" the ruler: "What faults has the one who shepherds the ruler?” One who shepherds the ruler is fond of the ruler" (Mengri 1B:4.10). When asked, "What must a ruler be like so that ministers will wear mourning clothes for him [i.e., properly honor him]?” Mengzi replies by listing the duties of a ruler to his ministers. Ideally, "The ministers' admonitions are put into effect; their teachings are listened to" (Mengæi 4B:3.3). In the case of a ruler whose ministers' "admonitions are not put into effect; [their] teachings are not listened to... This is called being an enemy. Why would one wear mourning clothes for an enemy?" (Mengzi 4B:3.4). Finally, in what is perhaps his most direct and forceful claim about the necessity of restraining the ruler, Mengzi recommends that "If the ruler makes some great mistake, then they [the ministers] remonstrate with him. If he does it repeatedly and does not listen to them, they remove him from office" (Mengzi 5B:9.1). ${ }^{\text {? }}$

Even in the context of the parent-child relation, authority can and should be challenged, albeit is a more deferential manner that recognizes the ultimately irreplaceable nature of filial relations:

In serving your parents you may gently remonstrate with them. However, once it becomes apparent that they have not taken your criticism to heart you should be respectful and not oppose them, and follow their lead diligently and without resentment. (Analects 4.18)

\footnotetext{
8 See Tiwald (2008) and Foust (2017).

${ }^{9}$ See also Mengzi 3B:2.2-2.3 on the error of “making obedience one's standard."
} 
Thus, even though one's remonstrations may go unheeded, Confucius recognizes them as valid and recommends them as compatible with "serving" one's parents.

The common thread connecting these different examples of "Confucian incivility" is that while they are disruptions of the normal $l i$-based social order, they are disruptions that aim at revitalizing that order rather than irreparably transgressing it (Kim 2011: 27). Kim (2011) argues that Confucian incivility is in fact necessary to temper the tendency toward an overly rigid and authoritarian society. Without specific practices of incivility, Confucian civility degenerates into docility. As we have seen above in examples from the Analects and the Mengri, Confucian incivility typically takes the form of specific discursive practices of remonstrative rebuke of one's parents or ruler. The key to a proper characterization of Confucian incivility is understanding it as aiming at harmonization (he/和), as opposed to identification (tong/同) (Kim 2011: 35). This key distinction comes in one of Confucius' characterizations of the gentleman as opposed to the petty man:

The Master said, “The gentleman harmonizes (be 和), and does not merely agree (tong 同). The petty person agrees, but he does not harmonize." (Analects 13.23)

In other words, exemplary engagement in the practices of $l i$ does not take the form of a docile, blind obedience. As already described above (Analects 3.12), li demands a certain presence of mind, a form of active engagement. The Confucian incivilities of remonstrating one's parents or rulers are in fact what harmonization, as opposed to mere agreement, requires in certain cases. In Slingerland's commentary on this passage, he cites the Zuo Commentary as the most helpful explanation of the distinction between harmonization and mere agreement. The commentary describes the Marquis of Qi discussing his minister, Ran Qiu, with Master Yan. After the Marquis declares that Ran Qiu is the only one who "harmonizes" with him, Master Yan corrects him, telling him that Ran Qiu might "agree," but he does not harmonize with the Marquis. When the Marquis inquires about the difference, Master Yan explains that harmonizing is like the work of the chef who balances and moderates ingredients by "strengthening the taste of whatever is lacking and moderating the taste of whatever is excessive." A further analogy is made with the way the disparate notes of music are brought together to harmonize; a minister who merely agrees is like trying to "season water with more water," or playing only a single note on the zither (Slingerland 2003: 150). ${ }^{10}$ Harmonious engagement with the $l i$-based social structure thus requires a kind of skillfulness - likened to the

\footnotetext{
10 See Legge (1991: 684) for the original translation of the Zuo Commentary that Slingerland (2003) cites.
} 
chef's or musician's - that involves not only knowing how to "follow the recipe" (so to speak), but also how to actively correct both excesses and deficiencies.

It is also important to note the general Confucian suspicion of popular opinion in connection with this point about incivility aiming at harmonization (he/和) rather than "mere agreement" (tong/同), especially in the case of Kaepernick. In his discussion of ritual, Xunzi's disdain for those who use ritual as an occasion to show off is clear:

Thus, when the changes in disposition and appearance are sufficient to differentiate good fortune and ill fortune and to make clear the proper measures for noble and lowly, close relations and distant relations, then ritual stops. To go beyond this is vile, and even should it be a feat of amazing difficulty, the gentleman will still consider it base. And so, to measure one's food and then eat it, to measure one's waist and then tie the mourning sash, to show off to those in high positions one's emaciation and infirmity - this is the way of a vile person. It is not the proper patterning of ritual and $y i$, it is not the true disposition of a filial son. It is rather the behavior of one acting for ulterior purposes. (Xun₹i 19.322-332) In the context of the mourning ritual, the way one expresses one's grief should be appropriate for the occasion. Xunzi's disdain in this passage is directed at those whose expressions of mourning are overblown, and thus likely just attempts to impress others. The critic of Kaepernick may actually try to employ this passage in their criticism, arguing that Kaepernick is guilty of precisely what Xunzi loathes. This claim - that Kaepernick is grandstanding - is indeed a common rebuke. But notice, however, that Xunzi is not criticizing intentional violations of ritual in this passage. His disapproval is not directed at incivility in a sense relevant to Kaepernick's case. Rather, he is criticizing those who make a great deal of the degree to which they are adhering to ritual. Thus, in the context of the contemporary American anthem ritual, I take this passage to more likely ground a critique of the degree to which the ritual has become an occasion for overly enthusiastic displays of patriotism - or, as I am interpreting Xunzi, overzealous displays of a "vile" or "base" pseudo-patriotism motivated by "ulterior purposes."

The mere performance of patriotism (as opposed to the authentic ritual expression of it) may look good in the public eye, but approval in the court of popular opinion is certainly not the measure of ritual propriety for the Confucian:

Zigong asked, "What would you make of a person whom everyone in the village likes?" The Master said, "I would not know what to make of him." "What about someone whom 
everyone in the village hates?" "I would still not know. Better this way: those in the village who are good like him, and those who are not hate him." (Analects 13.24) ${ }^{11}$

The classical Confucians thus seemed to have been well aware of the risk of ritual becoming an opportunity for grandstanding - for ingratiating oneself with one's superiors or the public. But as we have seen from the passages cited above, properly serving authority involves knowing when to push back. Furthermore, while the meaning of ritual is socially constituted to a certain extent (which we will turn to in more detail in the next sections), this does not entail that it is always properly expressed in the form of enthusiastic adherence to convention. Strategic violations of $l i$ - incivilities - have their place insofar as virtuous ritual practice aims at harmonization (he/和) rather than mere agreement (tong/同).

Existing work on the nature and role of Confucian incivility has done a great service to the study of Confucian philosophy. ${ }^{12}$ Thus far, however, this scholarship has focused on discursive or communicative forms of incivility - e.g., gentle remonstration of parents, or ministers speaking truth to political power. While this scholarship can help us begin to appreciate the significance of Kaepernick's gesture within a Confucian framework, work remains for a full-fledged Confucian appreciation of Kaepernick. For in the case of Kaepernick, we see Confucian incivility functioning at the bodily level within ritual itself. Kaepernick's gesture embodies Confucian incivility by subverting ritual from within. In other words, his gesture is a protest that disrupts the ritual while at the same time expressing a continued (albeit transformed) fidelity to it. The case of Kaepernick helps us see that from the political standpoint, rituals need not be understood solely in terms of a mechanism of state power to inscribe values upon the body politic. Rather, rituals can be subverted from within in such a way that disrupts while remaining reverent. In other words, for the Confucian, ritualized protest can be patriotic.

\footnotetext{
11 See also Analects 15.28: "The Master said, 'When the multitude hates a person, you must examine them and judge for yourself. The same holds true for someone whom the multitude love."'

12 I have cited Tiwald (2008), Kim (2011), and Foust (2017) in this regard, though it is worth emphasizing that Kim (2011) is the most systematic elaboration of the notion of "Confucian incivility," making a sustained case for its importance for contemporary political philosophy, namely as a resource for a more "socially and politically vibrant" form of communitarianism (Kim 2011: 34).
} 


\section{Ritual, Sagehood, Heritage}

Rituals operate on us in both cognitive and affective ways, giving proper shape to our responses to the social environment (Kline 2004: 195). Furthermore, for Xunzi, rituals establish the proper "differentiations" within the family and state:

What is meant by "differentiations"? I say: It is for noble and lowly to have their proper ranking, for elder and youth to have their proper distance, and for poor and rich, humble and eminent each to have their proper weights. (Xunzi 19.20-23)

The contemporary American national anthem ritual functions in this way, albeit the proper "differentiations" that it establishes are not hierarchical. Collectively standing and honoring the flag during the anthem cultivates feelings of peerhood and equality. And while Confucianism emphasizes hierarchical differentiations in general, the power of ritual—and ritualized music in particular — to cultivate non-hierarchical relations does not escape Xunzi's notice:

$[\mathrm{W}]$ hen music is performed in the ancestral temple and the ruler and ministers, superiors and inferiors, listen to it together, none fail to become harmoniously respectful. When it is performed within the home and father and sons, elder and younger brother listen to it together, none fail to become harmoniously affectionate. And when it is performed in the village, and old and young people listen to it together, none fail to become harmoniously cooperative. (Xunzi 20.17-23)

The sage-kings of Confucian lore instituted stable forms of communal life through ritual and music. Music unites and ritual differentiates, and are collectively the "height of the way" instituted by the sages to guide the people (Xunzi 20.55).

But in virtue of what special abilities or powers are the sages capable of such communityconstituting feats? In a discussion of the sacrificial rites, Xunzi explains that

The sage clearly understands them. The well-bred man and the gentleman are at ease in carrying them out. The officials take them as things to be preserved. The common people take them as their set customs. (Xunæi 19.567-570)

Furthermore, in differentiating a "man of standards" from the "standardless commoners," Xunzi distinguishes three further key traits:

To be able to reflect and ponder what is central to ritual is called being able to deliberate. To be able to be undeviating in what is central to ritual is called being able to be firm. When one can deliberate and be firm, and adds to this fondness for it, then this is to be a sage. (Xunzi 19.167-171) 
Clearly, for Xunzi, a central characteristic of the sage is a kind of moral clarity. The sage "clearly understands" ritual. The sage reflects and ponders what is central to ritual and achieves a kind of insight into its meaning. Presumably, this insight is connected to his ability to remain firm and even take pleasure in ritual.

While the sage's insight into the nature of ritual is certainly remarkable, we need not conceive of the sage as an individual genius who singlehandedly establishes ideal forms of social life. Rather, we can understand the sages as engaged in socially and historically extended projects of investigating and resolving certain questions about communal life, "rather than merely passing down proposed answers to them" (Hutton 2018: 184). Rituals emerge and develop through a diachronic process as sages take up the institutions of previous generations. This interpretation of sagehood and ritual was first suggested by David Nivison (1996) based on Xunzi's analogy likening the sage to the skilled craftsperson:

Someone asks: if people's nature is bad, then from what are ritual and yi produced? I answer: In every case, ritual and $y i$ are produced from the deliberate effort of the sage; they are not produced from people's nature. Thus, when the potter mixes up clay and makes vessels, the vessels are produced from the deliberate efforts of the craftsman; they are not produced from people's nature. Thus, when the craftsman carves wood and makes utensils, the utensils are produced from the deliberate efforts of the craftsman; they are not produced from people's nature. The sage accumulates reflections and thoughts and practices deliberate efforts and reasoned activities in order to produce ritual and yi and in order to establish proper models and measures. So, ritual and $y i$ and proper models and measures are produced form the deliberate efforts of the sage; they are not produced from people’s nature. (Xun₹i 23.92-105, my emphasis)

Importantly, as Hutton notes in his translation, the emphasized phrase in this passage can be alternately translated in the past tense and with a plural subject: "Sages accumulated reflections and thoughts and practiced deliberate efforts and reasoned activities...” (Hutton 2014: 250 fn. 4). The latter translation is especially conducive to Nivison's suggestion that the development of ritual proceeds in a piecemeal, diachronic process that spans generations, just as the techniques of pottery or woodworking. ${ }^{13}$

Hutton (2018) defends Nivison's reading of Xunzi, focusing on another key passage:

\footnotetext{
13 Van Norden (2011: 169-170) also interprets the passage this way, emphasizing the craftsmanship analogy.
} 
Those who cross waters mark out the deep places, but if the markers are not clear, people will fall in. Those who order the people mark out the Way, but if the markers are not clear, there will be chaos. The rituals are those markers. To reject ritual is to bemuddle the world, and to bemuddle the world is to create great chaos. (Xun₹i 17.238-242) $)^{14}$

This passage likens ritual to markers in a river that indicate depth and guide the passage of travelers. As Hutton observes, when one trusts the depth and placement of the markers, one thereby places one's trust in the judgment of those who placed them there in the past. These passages suggest a view of rituals as ongoing epistemic projects (Hutton 2018: 184). That is, we need not understand the sage's individual intentions as the sole source of ritual's "truth," but rather the way his actions ripple outward through social space and time. The exemplary members of subsequent generations who also possess the characteristic moral clarity will inevitably adjust and modify the institutions of previous sages as they actively take them up. The sage "may not himself see the finished 'product,' or even have intended to 'produce' it" (Nivison 1996: 328-9). Even if there is a single, allencompassing pattern or way (dao/道) that all ritual necessarily stems from, this is still compatible with different sages instituting different forms of ritual at different times because, as Hutton argues:

In terms of Xunzi's conception of the Way, the idea would be that its pattern was grasped at distinct points in history by each of the sage kings, and each created and passed down institutions that mark out that pattern, which helped subsequent sage kings to grasp the pattern. However, the parts of the pattern they grasped at different points in history were not entirely the same, and so their institutions were not entirely the same, either" (Hutton 2018: 188)

To be clear, commentators generally agree that Nivison's interpretation of Xunzi on this point is not definitive. Nivison himself acknowledges that Xunzi does not develop the idea in detail (Nivison 1996: 329). Nevertheless, I want to press ahead with the idea that sagehood and ritual are intertwined in a historical process of diachronic emergence and development because I find it to be a remarkably productive way of understanding the significance of Kaepernick's gesture, and I think it remains sufficiently continuous with both the letter of the Xunzi and the overall spirit of classical Confucianism. My interpretation of Kaepernick can thus be seen as lending support to Nivison's (1996) original suggestion, and Hutton's (2018) elaboration, insofar as it puts the view to work in order to see what kind of results it produces.

${ }^{14}$ See also Xunzi 27:58-65. 
Rather than simply sitting out the anthem ritual, Kaepernick chose to engage it in a unique way after deliberation (including consultation from his "minister," Nate Boyer). His deliberate effort, however, did not occur in a historical vacuum. His efforts are part of a larger "accumulation" of wisdom handed down from past figures. Kaepernick is part of a distinctive historical community whose leaders have continuously engaged in an ongoing project of working out the proper meaning and expression of patriotism. This historical community is not the Unites States understood as a single, homogenous community; but rather the African-American community. The leaders of this community have come from all areas of life, but great athletes are especially significant in this case.

As Bryant (2018) details, Kaepernick is part of a distinct heritage. Several great AfricanAmerican athletes of the $20^{\text {th }}$ Century have been rebuked for their perceived arrogance, ungratefulness, and disrespect upon protesting injustice. Paul Robeson and Muhammad Ali practiced discursive incivility in the form of speaking truth to power, discussed above. Robeson was a prolific activist with Communist sympathies who stood up to McCarthyism and was subsequently blackballed. Ali was openly critical of US foreign policy and refused to fight in Vietnam, leading to his imprisonment during the prime of his boxing career. Especially relevant to a discussion of Kaepernick, John Carlos and Tommie Smith raised their fists in the black power salute from the winners' podium during the American national anthem at the 1968 summer Olympics. Along these lines, Jackie Robinson, who is often celebrated for his humble determination and refusal to "get too political," found himself strongly provoked by and at odds with the affective power of the anthem ritual later in his life:

There I was, the black grandson of a slave, the son of a black sharecropper, part of a historic occasion, a symbolic hero to my people. The air was sparkling. The sunlight was warm. The band struck up the national anthem. The flag billowed in the wind. It should have been a glorious moment for me as the stirring words of the national anthem poured from the stands. Perhaps, it was, but then again, perhaps, the anthem could be called the theme song for a drama called The Noble Experiment. Today, as I look back on that opening game of my first World Series, I must tell you that it was Mr. Rickey's drama and that I was only a principal actor. As I write this twenty years later, I cannot stand and sing the anthem. I cannot salute the flag; I know that I am a black man in a white world. In 1972, in 1947, at my birth in 1919, I know that I never had it made. (Robinson 1972: 12) 
These figures have marked out the "deep places" in the "waters" that Kaepernick now finds himself crossing. ${ }^{15}$

The meaning of patriotism and its proper expression is a fraught issue for a community whose foundations are inseparable from the forcible subjugation of their ancestors. For AfricanAmericans especially, the national anthem ritual can concentrate generations of tension into an affect-laden bodily choreography that functions as what Bourdieu called a "call to order" (Bourdieu 1998: 54-55). Such calls to order "orient" us politically and culturally, putting us "in line," often quite literally (Ahmed 2006: 15). Political protest can resist this call to order by speaking truth to power, as Douglass, Robeson, and Ali did; but resistance can also occur at the deeper affective level of one's bodily involvement in the ritual, as seen in Smith and Carlos, and now Kaepernick.

Kaepernick's sagehood resides in the mimetic force of his gesture. He has provided a bodily grammar to express dissent in a way that engages the anthem ritual but does not refuse it. In this way Kaepernick's embodied resistance goes beyond the discursive forms of Confucian incivility outlined above. Remonstrating one's parent or ruler violates $l i$ insofar as it involves a subordinate challenging a superior. Kaepernick's taking a knee is thus remonstrative in the sense that his stated aim is to call out the abuse of state power as manifest in police brutality against African-Americans. Kaepernick's gesture, however, goes beyond discursive remonstration (he could do a speaking tour, or speak out on social media) by transforming a ritual meant to express loyalty into a corrective rebuke of the object of that loyalty.

Kaepernick has stated that he will stand for the anthem when he feels that the "flag represents what it is supposed to represent" (Dubin 2016). Thus, his embodied subversion of the anthem ritual aims at harmonization ( $h e /$ 和) in the sense outlined above; i.e., the aim is ultimately to rebalance what has become excessive. He is not rejecting the ritual or trying to tear it down. He is also not rejecting the value that the ritual expresses (patritotism, loyalty, reverence for country) or the object of that value (the nation). His gesture warrants analysis through the lens of Confucian incivility because it democratizes Confucian incivility in an important way. In the ancient Confucian context, efficacious incivility aimed at curbing abuses of state power could only be carried out by elite government minister. In contemporary America, everyone can speak out. But the power of "speaking out" varies due to the sheer volume of voices and capacity for collective attention.

\footnotetext{
15 Though not an athlete, closest thing to a primogenitor of Kaepernick's heritage may be Frederick Douglass. Although Douglass explicitly denied any sense of patriotism at one point in his life, he later cited his patriotic love of country as the very ground of his fierce social critique (Boxhill 2009: 303).
} 
Kaepernick finds himself in a unique role, with a powerful platform (famous professional athlete). But his protest goes beyond prior instances of black athletes speaking out (literally giving speeches or co-signing statements) against the state precisely in virtue of its bodily format. Taking a knee during the anthem at sporting events is a gesture easily imitated and powerfully visible. The nature of the ritual is such that hundreds or thousands of people's attention is trained on a central position occupied by the athletes on the field. While press release or social media post are easily ignored, a row of athletes at the center of the anthem ritual that begins every sporting event in America are not.

Consider, for example, the recent case of eight basketball players for the University of Mississippi who knelt during the anthem in order to protest their university's granting permission for multiple pro-Confederacy groups to march on campus. ${ }^{16}$ Experiencing powerful emotions and finding themselves needing to express themselves somehow, Kaepernick's gesture not only gave them something to say, but gave them a perfect way of saying it. And this, I am arguing, is precisely the mark of sagehood. Yes, Kaepernick's gesture aims at harmonization insofar as he is willing to return to the original ritual once society has corrected course. But Kaepernick's gesture is still importantly transformative in a way that aforementioned examples of Confucian incivility were not. The transformative power of his gesture lies in its bodily nature and thus its "mimetic force" - i.e. the way it affords widespread uptake. By turning now to a phenomenological analysis of ritual, we can articulate the significance of the bodily nature of Kaepernick's ritualized incivility and its social power thereby.

\section{The Phenomenology of ritual}

Applied to Confucian discussions of ritual, the descriptive analytical tools of phenomenology can offer a robust picture of the intersection of intersubjectivity, historicity, and the affective body. In this section I highlight five areas of Confucian ritual that phenomenology can further elucidate: (1) the nature of the dependence relation between ritual (li/裡) and one's humanity or goodness (ren/仁); (2) the normativity of habit; (3) the historical and communal nature of ritual; (4) the moral phenomenology of style; and (5) the mimetic or "citational" force of ritual gesture.

\footnotetext{
16 Bogage (2019)
} 


\subsection{Ren (仁) motivates li (禮)}

Several commentators have advanced an understanding of ritual as a kind of cultural “grammar" (Kline 2004; Li 2007; Bockover 2012). ${ }^{17}$ The idea is that the system of $l i$ constitutes a framework for the expression of one's underlying goodness or humanity, just as a system of grammar constitutes a framework for linguistic expression. Chenyang Li (2007) posits six similarities between grammar and $l i$ : (1) Both are essentially public phenomena - the actions that constitute $l i$ only have meaning in a social context; (2) Both are rooted in tradition; (3) Both have a descriptive function; (4) Both are instrumental for learning language/culture; (5) Both have a normative or prescriptive function; (6) Both remain largely constant, but can change over time.

$L i$ cannot be understood independently from the Confucian understanding of virtue, specifically the notion of ren (仁) - "goodness," "human excellence," "benevolence," or "humanity." Ren is the supreme virtue, the perfectionist ideal of Confucian ethical theory. Ren is achieved through the practice of $l i$. But the precise nature of the relation between ren and $l i$ is complex. ${ }^{18}$ On some accounts, $l i$ is instrumental to ren, but ren is an internal state of an agent that can exist independently of its expression in through li. Opposed to this instrumentalist account is the idea that ren cannot exist independently of its expression through $l i$, and thus that $l i$ quite literally constitutes ren. ${ }^{19}$

$\mathrm{Li}$ (2007) offers the most nuanced account of the relation between ren and $l i$, and, I argue, one largely identical to the phenomenological understanding of the relationship between thought and linguistic expression. For Li, $l i$ is a necessary but insufficient condition for the attainment of ren. Ren is a kind of mastery of a particular culture, and thus ren requires a system of cultural rules and norms for its expression—ren needs expression in $l i$. "In other words, without $l i$ there can be no culture for the person of ren to master" (Li 2007: 323-324). But the claim that li constitutes ren in the sense of being identical to it is too strong, since "Confucius holds that li may not always result in ren and that persons of ren may not always follow the rules of $l$ " (Li 2007: 314). In other words, adherence to $l i$ as a mere empty formalism is not sufficient for ren. ${ }^{20}$

\footnotetext{
${ }^{17}$ It should be noted that Bockover notes some discomfort with "talking about li as (cultural) grammar only because that seems to tie it conceptually (even if unwittingly) to written and verbal expression...but in the end this word choice may not make too much philosophical difference" (Bockover 2012: 181 n. 16)

${ }^{18}$ It is important to note here that in addition to understanding li as a set of rituals or rules of propriety, Mengzi understood $l i$ as an internal virtue along with ren, $y i$ (righteousness), and zhbi (wisdom). The relationship between ren and $l i$ that I am discussing in this section is primarily based on the Analects and various commentaries on it, although I do not take the phenomenological point I am making in this section to be incompatible with Mengzi.

19 This taxonomy follows Li (2007), who is summarizing Shun's (1993) original way of laying out these possible positions.

${ }_{20}$ See $\$ 3$ above on the difference between he and tong. The petty man merely adheres to $l i$ and thus lacks ren.
} 
This account is fundamentally analogous to the phenomenological understanding of the relation between thought and linguistic expression. For Merleau-Ponty, thought motivates expression. Motivation is a peculiar phenomenological concept, introduced by Husserl in the Logical Investigations and pervasive throughout his corpus, and central to Merleau-Ponty's Phenomenology of Perception. The concept of motivation designates a dependence relation between aspects of a phenomena that are analytically distinct but are lived through as an experiential whole. Thus, for example, thought needs expression in the sense that language - along with the grammatical rules for its expression - is necessary for individuating thought. But language is not constitutive of thought because linguistic expression is underdetermined by the thought it expresses. One can express herself and still feel as though the words she chose did not adequately articulate the underlying thought that motivated the expression. Articulation is the activity of putting something indeterminate (but not utterly inchoate or senseless) into determinate form (grammatical form).

\subsection{Rituals and the habit body}

As Merleau-Ponty put it, phenomenology developed the concept of motivation because it requires "“fluid' concepts that must be formulated if we want to return to phenomena," i.e. to remain faithful to the phenomena it seeks to elucidate (Merleau-Ponty 2012: 51). Motivation operates between the intellectualist notion of logical entailment and the blind causality of empiricism. We see the same idea in Bourdieu, who, following Merleau-Ponty, analyzed ritual as a paradigmatic case of motivated human activity. As Crossley puts it:

[Bourdieu] seeks to locate human life...somewhere between absolute mechanism and absolute voluntarism. Ritual activities are meaningful, purposive, and "mindful" in contrast to the mere mechanical responses posited in, for example, behaviorist conceptions of "reflexes." And yet, contrary to the intellectualist tradition, they are not steered by or thematized within reflective thought. They are precisely pre-reflective. (Crossley 2004: 40)

Another way of putting this is in terms of Merleau-Ponty's notion of habit. For Merleau-Ponty (and other phenomenologists) habit can be understood precisely as pre-reflective behavior that functions in the motivational domain between explicit deliberation and blind reflex. Repetition reinforces certain "motivational flows" within human activity, resulting in the "sedimentation" of habitual routines. Habits are "preestablished circuits" for coping with the world that become "privileged" by being “confirmed often enough" (Merleau-Ponty 2012: 89, 466). 
Habitual routines with their attendant motivational phenomenology are inherently normative phenomena. As Wehrle puts it, "On a concrete level, we can understand the experiencing body itself as 'normative,' in that it generates norms through repeated actions and interactions, crystallizing into habits" (Wehrle 2017: 325). The motivational phenomenology of habitual routines operates as a felt "tension that oscillates around a norm," governing the sensori-motor flow of activity in its concrete unfolding (Merleau-Ponty 2012: 316). Bodily habits crystalize through the repeated confirmation of certain movements that properly "gear into" a situation, providing a felt "hold" (or lack of hold) on one’s world (Merleau-Ponty 2012: 153, 265, 310). Merleau-Ponty's analyses mainly concern perceptual habits and the perceptual world, but the phenomenological "world" includes the sociohistorical world of cultural meanings and correlative habits as well, which in their most rigid formalization constitute a system of proprietary standards along the lines of Confucian $l i$.

\subsection{Ritual and the historical, intercorporeal body}

This is not to claim that all habits are rituals. There is an important intersubjective and communal dimension of ritual that differentiates it from everyday sensori-motor skills. But the phenomenological tradition includes additional resources to help us precisely account for this social and political dimension of Confucian $l i$. First of all, despite a certain caricatured notion, phenomenology is compatible with the general thrust of semantic externalism (Smith 2008).

Meaningful "content," for the phenomenologist, can only be individuated in terms of the intentional objects of experience. Phenomenology is "correlation" research, whereby lived experience is meaningful in virtue of its intentional relation to an external world. More specifically, in the case of linguistic and cultural meaning, the phenomenologist recognizes the necessity of "historicity" - a trans-generational intersubjective set of conditions for individuating meaningful content. ${ }^{21}$ Thus, ritualized gestures mean what they mean in virtue of a process of intersubjective historical sedimentation.

What phenomenology adds to the externalist way of individuating content, however, is its emphasis on how that content is "lived." The content of experience (what Husserl called its noema) has an affective salience that motivates a horizon of further possible experience. The perceived side of a house motivates an implicit sense of the further sides of the house that could be brought into view. The meanings constitutive of one's socio-cultural lifeworld are similarly motivational, insofar

\footnotetext{
21 The literature on this topic is vast, but for a good introduction to the roles of intersubjectivity and historicity in the transformation of Husserl's transcendental philosophy, see Carr (1974) and Zahavi (1996).
} 
as expressive behavior of others affords a more-or-less delineated horizon of possibilities for interaction. Merleau-Ponty describes this as the "intercorporeity" of the body, whereby intersubjective recognition is inherently a form of interactive "coupling" (Merleau-Ponty 2012: 334). This Merleau-Pontyan idea has been developed in great detail by several feminist philosophers, who emphasize the deeply affective and corporeal manner in which a general and anonymous sense of what is "normal" is inscribed on the body. ${ }^{22}$ Diprose (2008), for example, describes our inherent bodily openness to others with the concepts of "corporeal giving" and "corporeal generosity" - i.e., the iterative socialization processes whereby we pre-reflectively give and receive habits, gestures, and postures.

On one hand, the set of historically constituted shared meanings constitutive of a cultural tradition are essential for a subject to have a vocabulary for meaningfully expressing herself. Confucian $l i$ "allows one to become part of a culture in virtue of a shared ritualized body language perhaps as vital as the words we use to verbally communicate" (Bockover 2012: 181). On the other hand, of course, the anonymous normality that comes to govern one's sense of propriety in the domain of expressive behavior can be the vehicle for preserving oppressive power relations. Rituals have the power to foster continuity of practice, social meanings, and identity across generations in virtue of "their power to tap into the deeper corporeal basis of human subjectivity" (Crossley 2004: 32). In this way, rituals are a powerful mechanism for the inscription of ideology on the affective body. Cultural beliefs and norms become "incorporated" directly into the body schema in a way that is essentially similar to Merleau-Ponty's discussion of how skills and artifacts become incorporated into our sensori-motor habits (Malmqvist and Zeiler 2010; Zeiler 2013). As Wehrle puts it, "passive layers of experience are permeable to historical discourses, such that norms are literally incorporated" (Wehrle 2017: 325, my emphasis). While at one level the body is capable of forging its own norms through the repeated confirmation of specific sensori-motor routines that give us a perceptual grip on the world, at the cultural level there is

a necessary intertwinement between experience and the discursive realm, especially with regard to the operation of norms and embodiment...for norms to be effective, discourses are insufficient - they must be experienced and embodied...practices of 'discipline' 'inscribe' power constellations and discourses into subjective experience and bodies. (Wehrle 2017: 324)

22 See Weiss (2015) for discussion. 


\subsection{Style and moral exemplars}

Recall, however, that the phenomenological notion of motivated activity operates between explicit deliberation and blind mechanism. Rituals can function as a political technology for inscribing values at the affective bodily level, but the bodily "disciplining" thereby achieved is not rigidly deterministic. We feel the affective pull of rituals. It may be difficult to remain seated during the national anthem, but it is not impossible. Likewise, as previously discussed, the way one engages with ritual can range from thoughtful presence to a mere going through the motions, and this matters to the Confucian. Confucianism and phenomenology intersect again here, with the concept of style. Merleau-Ponty adopts the notion of style from aesthetics, claiming that we recognize the meaning of others' expressive behavior in virtue of it having an "expressive unity" akin to the unity found in a work of art (Merleau-Ponty 2012: 152ff.). Through a history of continuous interaction with my perceptual and social world, I incorporate bodily habits for negotiating myriad situations and maintaining an optimal grip on my milieu. But in the course of the motivational flow constitutive of my dealings with the world, I have room to "play" and develop a distinctive style. The motor habits we incorporate are subject a constant play of modification and refinement. Think, for example, of learning the steps of a dance "by the book" at first, after which one gradually and more or less subtly develops a peculiar style of one's own.

For the Confucian the same process is at play in how we adopt and subsequently engage ritual. Recall the importance of exemplarity to Confucian moral theory: sagehood resides not only in deliberation and insight, but also in the ability to convey one's virtue in a public way, such that others are moved by it. Feelings of admiration are a significant feature of Confucian moral phenomenology, as admiration indicates something worthy of imitation (Zagzebski 2015; 2017; Olberding 2008). The sage is not only an exemplar of doing what is right, but of effortless grace, seamless performance, and an overall aesthetic that elicits admiration in others. As Olberding puts it, the Confucian moral exemplar "is effective at conveying her dispositions in the medium of her demeanor, and her demeanor is received by relevant witnesses as appropriate and well styled" (Olberding 2009: 503). If ritualistic action, such as serving one's parents food or expressing grief during funeral rites, were a matter of mere mechanism, there would be no aesthetic dimension to it, no style. But as is clear in numerous places in classical Confucian texts, propriety in ritual action is far more than a matter of adhering to rules. It is a stylized performance with a unique aesthetic power. 


\subsection{Sagehood as bodily citational force}

Tying these threads together, we get a rich phenomenological picture of Confucian ritual and sagehood. Ritual is a form of cultural grammar, a framework in which one expresses and thereby cultivates virtue. Like linguistic grammar, this framework is inscribed on individuals through an iterative process of learning, correction, and reinforcement. The intercorporeal body is receptive to the habits and gestures of others and thereby "incorporates" cultural meanings. Also like linguistic grammar, mastery of this framework goes beyond adherence to the ability to develop a distinctive style through subtle modification and innovation. Sagehood consists of a kind of virtuosity whereby the way one comports oneself, both discursively and in bodily style, elicits admiration and thus imitation. Given the intersubjective historical conditions necessary for individuating the meaning of expressive gestures, this exemplarity of the sage exists as a kind of bodily "citational force." 23 That is, the moral authority of the sage, manifest in his ability to steer the course of ritual and thus the historical flow of cultural meaning and value, is not simply a matter of his individual will or intention, but rather just is his power to institute new body language that others take up and find useful in developing their own expressive style. Kaepernick's sagehood, I argue, consists in the unique citational force of his gesture - taking a knee - as opposed to other forms of ritualized, embodied protest. He has, as Fingarette puts it, "labored at the alchemy of fusing social forms ( $l i$ ) and raw personal existence in such a way that they transmuted into a way of being which realizes te [de/德], the distinctively human virtue or power” (Fingarette 1972: 7).

\section{Ritual resistance and the phenomenology of excorporation}

The raised fist of the black power salute is a good example of a ritualized body language that has taken on a historically sedimented meaning precisely through its citational force. Kaepernick's taking a knee, however, is interestingly different. The raised fist has been adopted by many causes throughout history: from European anti-fascists, to $19^{\text {th }}$ and $20^{\text {th }}$ century labor movements, to the black power movement. It embodies strength, solidarity, and defiance. Taking a knee, on the other hand, embodies reverence, deference, and humility. Both gestures, performed in the context of the anthem ritual, are examples of Confucian incivility at the level of the affective body. Whereas the

\footnotetext{
23 As Wehrle (2017) notes, this notion goes back to Judith Butler's notion of performativity, who in turn was adapting it from Derrida's theory of speech acts. Wehrle's note is worth citing at length: 'For Derrida the binding power of the [speech] act is not derived by the intention or will of the speaker, but rather stems from the citational force of speaking itself. It is the iterability which establishes the authority of the speech act. In this sense every speech act is an echo or citational chain, and it is this citationality that constitutes its performative force" (Wehrle 2017: 330-331 n. 22).
} 
phenomenology of incorporation discussed above describes a process of iterative inscription of social values upon the body, these gestures are revealing examples of excorporation. Zeiler and Malmqvist (2010; 2013) introduce the concept of “excorporation," which designates the way in which "one's lived body breaks in the encounter with others and how this makes one unable not to attend to certain beliefs and norms about one’s own lived body" (Zeiler 2013: 70). Recall Jackie Robinson's description of the difficulty of the anthem ritual above:

I cannot stand and sing the anthem. I cannot salute the flag; I know that I am a black man in a white world. In 1972, in 1947, at my birth in 1919, I know that I never had it made.

(Robinson 1972: 12)

The anthem ritual draws an irresistible thematic attention to certain beliefs and norms that have been incorporated and function at the pre-reflective bodily level. Whereas incorporation is an iterative process of gradual sedimentation of bodily routines, excorporation is often an abrupt, painful moment in which “one's lived body breaks in the encounter with others" (Zeiler 2013: 75). Fanon describes this phenomenon in Black Skin, White Masks when he recounts the way the pointing, stares, and exclamations of whites on public transit make it impossible for him to not to become painfully aware of the racialized meaning of his own body (Fanon 2008: 91-92).

I am suggesting that the anthem ritual is a common and unsurprising vehicle of excorporation for many African-Americans. The ritual is a "call to order" that puts us "in line" with the body politic, and thus makes focal the ideology that has crystalized into certain stylized bodily habits. Excorporation thus leads to feelings of alienation. One is forced to confront, at the bodily level, the growing gulf between one's own values and those one has incorporated. Coping with excorporation is difficult, for it calls for finding new bodily habits that run against the deeply engrained existing ones. One can "opt out” by refusing to engage the ritual. Kaepernick initially took this route by simply remaining seated during the anthem. ${ }^{24}$ But the sage does not opt out, the sage has insight into what is central to the ritual (as opposed to what has become ossified, and tangential to its purpose), and institutes new forms of bodily expression that remain faithful to the need the ritual satisfies while simultaneously issuing a corrective rebuke at what has become pernicious about it.

\footnotetext{
${ }^{24}$ Consider Marshawn Lynch, a highly successful NFL player (and thus well-known, heavily reported on, and in no way obscure or unremarkable), who reportedly has sat during the anthem for 11 years and was barely given notice in the press until the Kaepernick incident (Bair 2017).
} 


\section{Instituting a new patriotism}

The patriot is committed to an understanding of the nation as an ongoing project that one has responsibility for, like it or not. As MacIntyre puts it:

What the patriot is committed to is a particular way of linking a past which has conferred a distinctive moral and political identity upon him or her with a future for the project which is his or her nation which it is his or her responsibility to bring into being. Only this allegiance is unconditional and allegiance to particular governments or forms of government or particular leads will be entirely conditional upon their being devoted to furthering that project rather than frustrating or destroying it. Hence there is nothing inconsistent in a patriot's being deeply opposed to his country's contemporary rulers. (MacIntyre 2003: 295) Taking a knee expresses reverence, deference, and humility. It acknowledges an insufficiency. In the current historical moment, it is an appropriate expression for the national anthem ritual because it acknowledges the American ideal as precisely that, an ideal that we necessarily will fail to live up to, and yet one which we may still respect and honor. To stand with pride is perhaps to repress what we know to be true: that we are failing to live up to the ideal we marked out for ourselves. Just as filial piety can require gently remonstrating one's parents, so too does contemporary American patriotism. Kaepernick's gesture embodies this need for Confucian incivility, and does so in a way that does not defy or opt out, but rather solicits and invites while gently remonstrating. His gesture has rippled outward across race and age and beyond sport. It combines a kind of moral clarity —an insight into what this ritual ought to express and the attitudes about our collective past that it ought to cultivate-with a commitment to the need for stylized ritual expression, and thus, perhaps, gives us an idea of what a $21^{\text {st }}$ Century American sage might look like. 


\section{Acknowledgements}

I am grateful an anonymous reviewer whose critical feedback substantially improved the paper.

\section{References}

Ahmed, Sara (2006). Queer Phenomenology: orientations, objects, others. Durham: Duke University Press.

Angle, Stephen C. (2009). Sagehood. New York: Oxford University Press.

Appiah, Kwame Anthony (1997). Cosmopolitan patriots. Critical Inquiry 23 (3):617.

Bair, Scott (2017). Del Rio: according to Lynch, he's always sat during national anthem. NBC Sports. https://www.nbcsports.com/bayarea/raiders/del-rio-according-lynch-hes-always-sat-duringnational-anthem (accessed May 28, 2019).

Baron, Marcia (2002). Patriotism and "liberal" morality. In I. Primoratz (Ed.), Patriotism (pp. 59-86). Amherst: Humanity Books.

Bauer-Wolf, Jeremy (2019). Still taking a knee against racism. Inside Higher Ed. https://www.insidehighered.com/news/2019/02/19/college-students-are-still-taking-knee-againstracism (accessed May 28, 2019).

Bockover, Mary I. (2012). Confucian ritual as body language of self, society, and spirit. Sophia 51 (2):177-194.

Bogage, Jacob (2019). Mississippi basketball players kneel in protest during anthem as Confederate groups rally in Oxford. The Washington Post.

https://www.washingtonpost.com/sports/2019/02/23/mississippi-basketball-players-kneel-duringnational-anthem-confederate-groups-rally-oxford/ (accessed November 21, 2019).

Bourdieu, Pierre (1998). Practical Reason. Cambridge: Polity.

Boxhill, Bernard R. (2009). Frederick Douglass's patriotism. Journal of Ethics 13 (4): 301-317.

Breech, John (2016). Colin Kaepernick's practice socks appear to disrespect the police. CBS Sports. https://www.cbssports.com/nfl/news/look-colin-kaepernicks-practice-socks-appear-to-disrespectthe-police/ (accessed May 28, 2019).

Brinson, Will (2018). President Trump speaks out on new NFL national anthem policy, calls it 'stupid' and 'worse.' CBS Sports. https://www.cbssports.com/nfl/news/president-trump-speaks-outon-new-nfl-national-anthem-policy-calls-it-stupid-and-worse/ (accessed May 28, 2019).

Bryant, Howard (2018). The Heritage: black athletes, a divided America, and the politics of patriotism. Boston: Beacon Press.

Chaibong, Hahm (2001). Confucian rituals and the technology of the self: a Foucauldian interpretation. Philosophy East and West 51 (3): 315-324. 
Carr, David (1974). Phenomenology and the problem of history. Philosophy and Phenomenological Research 36 (4):578-580.

Clark, Dartunorro (2018). Democrat Beto O'Rourke, in viral video, defends NFL protests. NBC News. https://www.nbcnews.com/politics/politics-news/democrat-beto-o-rourke-goes-viralresponse-nfl-players-kneeling-n903176 (accessed May 28, 2019).

Coombs, Danielle S., Cheryl A. Lambert, David Cassilo, and Zachary Humphries (2017). Kap takes a knee: a media framing analysis of Colin Kaepernick's anthem protest. $20^{\text {th }}$ International Public Relations Research Conference Proceedings (pp. 48-62). www.instituteforpr.org/wpcontent/uploads/IPRRC20-proceedings_Final.pdf\#page=49 (accessed May 28, 2019).

Crossley, Nick (2004). Ritual, body technique, and (inter) subjectivity. In K. Schilbrack (Ed.), Thinking Through Rituals (pp. 31-51). New York: Routledge.

Curzer, Howard J. (2012). Contemporary rituals and the Confucian tradition: a critical discussion. Journal of Chinese Philosophy 39 (2): 290-309.

Davis, Amira R. (2018). Black athletes, anthem protests, and the spectacle of patriotism. Black Perspectives. https:/ / www.aaihs.org/black-athletes-anthem-protests-and-the-spectacle-of-patriotism (accessed May 28, 2019).

Diaz, Andrea (2018). Faith compelled Notre Dame students to take a knee during the national anthem to protest racism. CNN. https://www.cnn.com/2018/11/15/us/notre-dame-studentskneel-national-anthem-trnd/index.html (accessed May 28, 2019).

Diaz, Daniella (2016). Obama defends Kaepernick's anthem protest. CNN. https://www.cnn.com/2016/09/28/politics/obama-colin-kaepernick-nfl-national-anthempresidential-town-hall-cnn/index.html (accessed May 28, 2019).

Dubin, Jared (2016). Colin Kaepernick: I'll keep sitting for anthem until meaningful change occurs. CBS Sports. https://www.cbssports.com/nfl/news/colin-kaepernick-ill-keep-sitting-for-anthemuntil-meaningful-change-occurs/ (accessed November 20, 2019).

Fanon, Frantz (2008). Black Skin, White Masks. New York: Grove Press.

Fingarette, Herbert (1972). Confucius: The Secular as Sacred. Prospect Heights: Wavelength Press.

Foust, Mathew A. (2017). Confucianism and American Philosophy. Albany: SUNY Press.

Fritze, John (2018). Trump's toughest tweets knocking players for kneeling during national anthem. USA Today. https://www.usatoday.com/story/news/politics/2018/09/09/donald-trumpstoughest-tweets-kneeling-during-national-anthem/1248196002/ (accessed May 28, 2019).

Gomberg, Paul (1990). Patriotism is like racism. Ethics 101 (1):144-150. 
Graham, Bryan A. (2017). Donald Trump blasts NFL anthem protesters: 'Get that son of a bitch off the field.' The Guardian. https://www.theguardian.com/sport/2017/sep/22/donald-trump-nflnational-anthem-protests (accessed May 28, 2019).

Hutton, Eric L. (2018). Extended knowledge and Confucian tradition. In J.A Carter et al. (Eds.), Extended Epistemology (pp. 177-194). Oxon: Oxford University Press.

Hutton, Eric. L., trans. (2014). Xunzi: the complete text. Princeton: Princeton University Press.

Keller, Simon (2005). Patriotism as bad faith. Ethics 115 (3):563-592.

Kim, Sungmoon (2011). The virtue of incivility: Confucian communitarianism beyond docility. Philosophy and Social Criticism 37 (1):25-48.

Kline, T.C. (2004). Moral Cultivation through ritual participation: Xunzi's philosophy of ritual. In K. Schilbrack (Ed.), Thinking Through Rituals (pp. 194-212). New York: Routledge.

Li, Chenyang (2007). Li as cultural grammar: on the relation between li and ren in Confucius' Analects. Philosophy East and West 57 (3):311 - 329.

Legge, James, trans. 1991. The Ch'un Ts'ew with the Tso Chuen (The Chinese Classics, vol. V). Taipei: SMC Publishing.

MacIntyre, Alasdair (2003). Is patriotism a virtue? In D. Matravers and J. Pike (Eds.), Debates in Contemporary Political Philosophy (pp. 286-300). New York: Routledge.

Malmqvist, Erik, and Kristin Zeiler (2010). Cultural norms, the phenomenology of incorporation, and the experience of having a child born with ambiguous sex. Social Theory

and Practice 36 (1): 133-56.

Martin, Jill (2016). Colin Kaepernick: 'It would be hypocritical of me to vote.' CNN.

https://www.cnn.com/2016/11/14/sport/49ers-qb-colin-kaepernick-explains-why-he-didntvote/index.html (accessed May 28, 2019).

McCain, John, and Jeff Flake (2015). Tackling paid patriotism: a joint oversight report. https://static.politico.com/98/a4/d61b3cae45f0a7b79256cf1da1e0/flake-report.45am.pdf (accessed May 28, 2019).

Merleau-Ponty, Maurice (2012). Phenomenology of Perception. Translated by Donald Landes. London: Routledge.

Nivison, David (1996). Critique of David B. Wong, 'Xunzi on moral motivation.' In P.J. Ivanhoe (Ed.), Chinese Language, Thought, and Culture: Nivison and his critics (pp. 323-331). Chicago: Open Court.

Olberding, Amy (2008). Dreaming of the Duke of Zhou: exemplarism and the Analects. Journal of Chinese Philosopby 35 (4):625-639. 
Olberding, Amy (2009). "Ascending the hall": Style and moral improvement in the Analects. Philosophy East and West 59 (4):503-522.

Ortiz, Erik (2018). Football, the anthem, and taking a knee: One all-black high school team takes a stand. NBC News. https://www.nbcnews.com/news/sports/football-anthem-taking-knee-one-allblack-high-school-team-n919116 (accessed May 28, 2019).

Primoratz, Igor (2008). Patriotism and morality: mapping the terrain. Journal of Moral Philosophy 5 (2):204-226.

Robinson, Jackie (1972). I Never Had It Made. New York: Putnam.

Slingerland, Edward, trans. (2003). Analects: with selections from traditional commentaries. Indianapolis: Hackett Publishing Company.

Smith, A. D. (2008). Husserl and externalism. Synthese 160:313-333.

Sharon, Jeremy (2018). Jewish students "take a knee" during Hatikva in support of Palestinians. The Jerusalem Post. https://www.jpost.com/Diaspora/Jewish-students-take-a-knee-during-Hatikva-insupport-of-Palestinans-571921(accessed May 28, 2019).

Shun, Kwong-loi (1993). Jen and $l i$ in the Analects. Philosophy East and West 43 (3):457-479.

Tiwald, Justin (2008). A Right of Rebellion in the Mengzi? Dao: A Journal of Comparative Philosophy 7 (3):269-282.

Van Norden, Bryan, trans. (2008). Mengzi: with selections from traditional commentaries. Indianapolis: Hackett Publishing Company.

Wehrle Maren (2017). The normative body and the embodiment of norms: bridging the gap between phenomenological and Foucauldian approaches', in Feger, Dikun, and Ge (Eds.), Yearbook of Eastern and Western Philosophy (De Gruyter), Issue 2, pp. 323-337.

Weiss, Gail (2015). The normal, the natural, and the normative: a Merleau-Pontian legacy to feminist theory, critical race theory, and disability studies. Continental Philosophy Review 48:77-93.

Zagzebski, Linda (2015). I-Admiration and the admirable. Aristotelian Society Supplementary Volume 89 (1):205-221.

Zagzebski, Linda (2017). Exemplarist Moral Theory. New York: Oxford University Press.

Zahavi, Dan (1996). Husserl's intersubjective transformation of transcendental philosophy. Journal of the British Society for Phenomenology 27 (3):228-245.

Zeiler, Kristin (2013). A phenomenology of excorporation, bodily alienation, and resistance: rethinking sexed and racialized embodiment, Hypatia 28 (1):69-84. 